Vol 5 No 1 February 2020

E-ISSN: 2528-410X

ORIGINAL ARTICLE

\title{
Comparison of Antioxidant and Anti-Tyrosinase Activity between Black Soybean (Glycine max (L.) Merr.) and Daidzein
}

\author{
Delken Kuswanto', I Nyoman Ehrich Lister ${ }^{2}$, ErmiGirsang ${ }^{3}$, Ali NapiahNasution ${ }^{4}$, \\ Wahyu Widowati ${ }^{5}$ \\ ${ }^{1}$ Master Program of Biomedical Sciences, Universitas Prima Indonesia, Medan, Indonesia, \\ ${ }^{2}$ Faculty of Medicine, Universitas Prima Indonesia, Medan, Indonesia, \\ ${ }^{3}$ Faculty of Public Health, Universitas Prima Indonesia, Medan, Indonesia, \\ ${ }^{4}$ Department of Tropical Medicine, Faculty of Medicine, Universitas Prima Indonesia, Medan, Indonesia, \\ ${ }^{5}$ Faculty of Medicine, Maranatha Christian University, Bandung, Indonesia
}

Corresponding E-mail: ermigirsang@ unprimdn.ac.id

\begin{abstract}
Free radicals in the body will increase with excessive ultraviolet (UV) light exposure, induce oxidative stress with the formation of Reactive Oxygen Species (ROS). A visible effect on skin tissue known as photoaging, including the process of melanogenesis catalyzed by the tyrosinase enzyme, risked for pigmentation or melanoma disorder.

The use of natural ingredients has been widely used by the community to prevent the aging process. Natural compounds from a plant can be a source of antioxidants and have anti-aging abilities through inhibition of the tyrosinase enzyme. Black soybean (Glycine max (L.) Merr.) are high in the isoflavone compound, one of which is daidzein.

This study evaluates the antioxidant and anti-aging potential of black soybean extract with daidzein. Antioxidants using the DPPH method and anti-aging tests carried out, namely the inhibition of the tyrosinase enzyme, are very important in the aging process.

Daidzein has an $\mathrm{IC}_{50}$ value of DPPH scavenging activity around $109.34 \pm 2.80 \mu \mathrm{g} / \mathrm{mL}$ lower than black soybean extract with $116.52 \pm 2.50 \mu \mathrm{g} / \mathrm{mL}$. Results on tyrosinase enzyme inhibition activity, black soybean extract had an $\mathrm{IC}_{50}$ value of $70.71 \pm 1.83 \mu \mathrm{g} / \mathrm{mL}$ lower compared to daidzein with $72.65 \pm 2.81 \mu \mathrm{g} / \mathrm{mL}$. In contrast to the better antioxidant activity of daidzein, the black soybean extract is more potential to inhibit the enzyme tyrosinase.
\end{abstract}

Keywords: black soybean, daidzein, antioxidant,anti-aging, anti-tyrosinase

\section{INTRODUCTION}

The aging process is a physiological process that will occur in every living thing and the skin is a body tissue that gives a visual image of aging. Skin aging is a complex process influenced by genetic, environmental and nutritional properties. (1) Excessive ultraviolet (UV) light exposure increases the contribution of free radicals known as Reactive Oxygen Species (ROS). This certainly influences the process of melanogenesis on the skin catalyzed by the 
enzyme tyrosinase. This enzyme regulates skin pigmentation through the synthesis of melanin. Increased UV radiation will increase the synthesis of melanin which causes a risk of pigmentation or melanoma disorders. ${ }^{(2)}$

Various types of modern medicine have been applied to prevent premature aging, one of which is cosmetic. Most cosmetics have side effects and are not safe, so natural ingredients are needed. ${ }^{(3)}$ Currently, natural herbal plants are getting attentions to solve problems. The use of traditional material has long been used by the community as an alternative treatment, for disease prevention, healing, health recovery and improving health status. Based on WHO data, mentioning Africa, Asia and Latin America using traditional materials as a complement to their primary treatment. ${ }^{(4)}$

The use of natural materials as traditional ingredients has also been carried out by Indonesia since the days of our ancestors. The tendency of the use of traditional ingredients in the world is caused by plants containing compounds that are efficacious in medicine known as phytochemical compounds, namely a group of natural compounds that can be used to maintain health and treat diseases due to their antioxidant activity. ${ }^{(5)}$

In Indonesia, black soybeans are one of the plants which are the main food commodities after rice and corn. ${ }^{(6)}$ Black soybeans contain high carbohydrates, vitamins, minerals, and proteins. ${ }^{(7)}$ Besides, the advantages of black soybean plants have the most content of isoflavones (one of them is daidzein) which acts as an antioxidant, only produced from plants and found in legumes. (8) Lately, antioxidants have become somewhat interesting in the medical world, known to have the effect of preventing premature aging (anti-aging) in fighting free radicals. ${ }^{(9)}$

It is necessary to conduct a study of the activity of black soybean extract as an antioxidant and anti-tyrosinase with the daidzein comparison compound. This needs to be done to prove the effectiveness of the black soybeans so that black soybeans can be used as natural food to slow down the aging process.

\section{METHODS}

\section{Preparation of Black Soybean (Glycine $\max ($ L.) Merr.) Extract}

Black soybean seeds (Glycine max (L.) Merr.) are washed and dried. Glycine max (L.) Merr.) were milled and extracted using $70 \%$ ethanol by maceration method for 3 days at room temperature. The filtrate was evaporated with a rotary evaporator so that a thick extract was obtained in paste form. ${ }^{(10)}$

\section{Qualitative Phytochemical Screening} Assay

\section{Flavonoid Identification}

The test tube containing $\mathrm{HCl} 2 \mathrm{~N}$ was dissolved by mixing $10 \mathrm{mg}$ Glycine $\max$ (L.) Merr.) into it. $\mathrm{Mg} / \mathrm{Zn}$ is added enough and heated for 10-15 minutes. Amyl alcohol 1 $\mathrm{ml}$ added to the test tube has been cooled and filtered. The presence of a red/orange 
color indicates the sample contains a flavonoid compound. ${ }^{(11)}$

\section{Saponin Identification}

Glycine $\max$ (L.) Merr.) (10 mg) was dissolved using $\mathrm{ddH}_{2} \mathrm{O}$ in a test tube, simmer for 5 minutes. $\mathrm{HCl} 1 \mathrm{~N}$ is added to the solution which has been filtered and shaken strongly. The presence of foam that is still present and remained stable shows a sample containing a saponin compound. ${ }^{(11)}$

\section{Phenol Identification}

Glycine max (L.) Merr.) $10 \mathrm{mg}$ dissolved

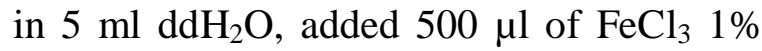
solution. The presence of green/red/purple/blue/black color indicated Glycine $\max ($ L.) Merr.) contains phenol compounds. ${ }^{(11)}$

\section{Tannin Identification}

$\mathrm{HCl} 2 \mathrm{~N}$ around $2 \mathrm{mg}$ was dissolved with $10 \mathrm{mg}$ of Glycine $\max$ (L.) Merr.) in a test tube, heated in a water bath for 30 minutes. Amyl alcohol $500 \mu \mathrm{l}$ is added after the solution cooled down. Orange/red color in the amyl alcohol layer indicated a tannin compound. ${ }^{(11)}$

\section{Alkaloid Identification}

Glycine $\max$ (L.) Merr.) $10 \quad \mathrm{mg}$

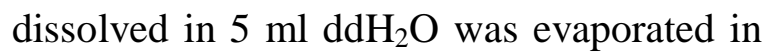
the water bath. The resulting residue is added $5 \mathrm{ml} \mathrm{HCl} 2 \mathrm{~N}$. The solution obtained is divided into 2 test tubes. The first tube is added 3 drops of $\mathrm{HCl} 2 \mathrm{~N}$ which functions as a blank. The second tube solution was transferred as much as one drop to the drip plate, then added 3 drops of Dragendorff reagent. The orange deposits formed indicate the presence of alkaloids. ${ }^{(11)}$

\section{Steroid/Triterpenoid Identification}

The drip plate contains $10 \mathrm{mg}$ Glycine $\max ($ L.) Merr.), added glacial acetic acid until submerged, left for 10-15 minutes and added with a drop of concentrated $\mathrm{H}_{2} \mathrm{SO}_{4}$. The presence of a blue-green color indicated the sample contains a steroid compound, whereas if it shows purple/red/orange color, the sample contains the triterpenoid compound. $^{(11)}$

\section{Terpenoid Identification}

Vanillin is added enough to the drip plate containing $10 \mathrm{mg}$ of Glycine $\max (\mathrm{L}$.) Merr.) Addition of one drop $\mathrm{H}_{2} \mathrm{SO}_{4}$ into it and homogenize. The presence of purple color contains the terpenoid compound. ${ }^{(11)}$

\section{DPPH (2,2-diphenyl-1-picryl-hydrazyl-} hydrate) Assay

DPPH $0.077 \mathrm{mmol} 200 \mu \mathrm{l}$ in methanol was added to each $50 \mu \mathrm{l}$ of Glycine $\max (\mathrm{L}$.) Merr.) extract and daidzein respectively on the microplate. The mixture was incubated at room temperature for 30 minutes. DPPH $250 \mu \mathrm{l}$ for negative control. The absorbance value is measured at a wavelength of 517 $\mathrm{nm}$ using a microplate reader. ${ }^{(12)} \mathrm{DPPH}$ methodantioxidant activity $(\%)$ :

DPPH scavenging activity $(\%)=1-\frac{\text { sample }}{\text { control }} \times 100$ 
E-ISSN: 2528-410X

\section{Tyrosinase Inhibitor Assay}

The mixture consisted of $20 \mu$ lGlycine $\max ($ L.) Merr.), $20 \mu$ lTyrosinase from Mushroom (125 U/ml) enzyme, and $140 \mu \mathrm{l}$ potassium phosphate buffer $(20 \mathrm{mM}, \mathrm{pH}$ 6.8) were incubated at room temperature for 15 minutes. The control contained $20 \mu \mathrm{l}$ enzyme and $160 \mu \mathrm{l}$ phosphate buffer, then added $20 \mu \mathrm{l}$ of L-DOPA substrate $(1.5 \mathrm{mM})$ and incubated again at 10 minutes. The absorbance is measured using a wavelength of $470 \mathrm{~nm} .{ }^{(13)}$ The percentage of tyrosinase inhibitor activity is calculated using the formula:

scavenging activity $(\%)=\frac{\text { control }- \text { sample }}{\text { control }} \times 100$

\section{RESULTS}

\section{Phytochemical Screening of Glycine Max} (L.) Merr.)

Phytochemical screening of black soybean seed extract (Glycine max (L.) Merr.) includes alkaloid, tannin, steroid/triterpenoid, phenol, saponin, flavonoid, and terpenoid. Some of this substrate or component can affect the ability of antioxidants, such as alkaloid and terpenoid. The phytochemical test results provide an overview of the classes of compounds contained in Glycine $\max (\mathrm{L}$.) Merr.) which is saponin, tannin, triterpenoid, terpenoid, alkaloid, and can be seen in Table 1.

\section{DPPH Scavenging Activity}

The result of the antioxidant activity test using the DPPH method in various concentrations can be seen in Table 2 and

Buletin Farmatera

Fakultas Kedokteran (FK)

Universitas Muhammadiyah Sumatera Utara (UMSU)

http://jurnal.umsu.ac.id/index.php/buletin_farmatera
Figure 1 with Tukey HSD statistical analysis. In the process of analyzing whether Glycine $\max$ (L.) Merr). and the daidzein compound has antioxidant activity, it can be seen as a linear regression equation to find IC50 values in Table 3.

Table 1. Phytochemical Screening of Glycine max (L.) Merr.)

\begin{tabular}{lc}
\hline \multicolumn{1}{c}{ Contain } & Result \\
\hline Flavonoid & - \\
Saponin & + \\
Phenol & - \\
Tanin & + \\
Steroid/triterpenoid & $-/+$ \\
Terpenoid & + \\
Alkaloid & + \\
\hline
\end{tabular}

Table 2. DPPH Scavenging Activity

\begin{tabular}{lcc}
\hline $\begin{array}{c}\text { Concentration } \\
(\boldsymbol{\mu} \mathrm{g} / \mathrm{ml})\end{array}$ & \multicolumn{2}{c}{ Average DPPH Scavenging (\%) } \\
\cline { 2 - 3 } & $\begin{array}{c}\text { Glycine max } \\
(\mathrm{L} .) \text { Merr. }\end{array}$ & Daidzein \\
\hline 200 & $65.01 \pm 2.02^{\mathrm{c}}$ & $67.87 \pm 1.02^{\mathrm{e}}$ \\
100 & $49.85 \pm 0.84^{\mathrm{b}}$ & $50.88 \pm 0.98^{\mathrm{d}}$ \\
50 & $34.52 \pm 1.25^{\mathrm{a}}$ & $37.88 \pm 0.46^{\mathrm{c}}$ \\
25 & $31.59 \pm 1.10^{\mathrm{a}}$ & $30.96 \pm 0.44^{\mathrm{b}}$ \\
12.5 & $31.97 \pm 1.99^{\mathrm{a}}$ & $29.24 \pm 0.51^{\mathrm{a}, \mathrm{b}}$ \\
6.25 & $29.90 \pm 3.07^{\mathrm{a}}$ & $27.57 \pm 1.23^{\mathrm{a}}$ \\
\hline
\end{tabular}

Notes:

Data were presented as mean \pm standard deviation. Different small letters in the same column are significant at $P<.05$ (Tukey HSD Post Hoc test).

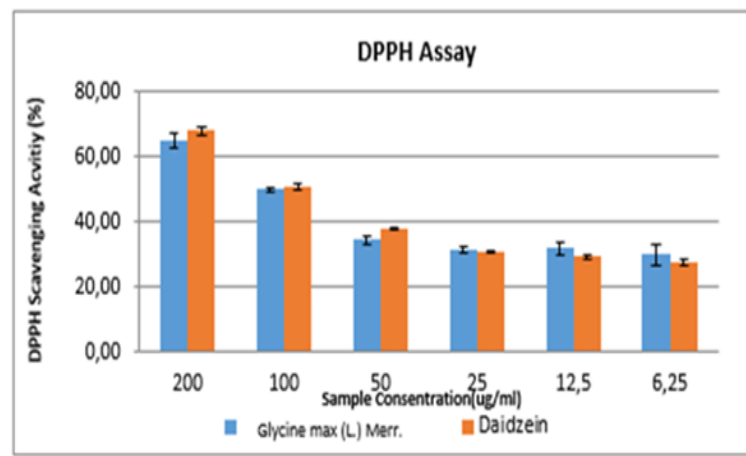

Figure 1. Various concentrations in DPPH method 
Vol 5 No 1 February 2020

E-ISSN: 2528-410X

The antioxidant activity test used DPPH scavenging activity parameters as seen in Table 2, where Glycine $\max$ (L.) Merr). and daidzein had the highest antioxidant activity at a concentration of $200 \mu \mathrm{g} / \mathrm{ml}$, each at $65.01 \pm 2.02 \%$ and $67.87 \pm 1.02 \%$. The lower the concentration shows the smaller the percentage of antioxidant activity of Glycine $\max ($ L.) Merr). and daidzein.

Tabel 3 shows that Glycine $\max$ (L.) Merr). and daidzein with DPPH scavenging activity obtained IC50 values averaging 116.52 \pm 2.50 $\mu \mathrm{g} / \mathrm{ml}$ and $109.34 \pm 2.80 \mu \mathrm{g} / \mathrm{ml}$.

\section{Tyrosinase Inhibitor Activity}

The test results of tyrosinase enzyme inhibition activity in various concentrations can be seen in Table 4 and Figure 2. The test results of tyrosinase inhibition activity in both samples were linear regression equations to find the IC50 value in Table 5.

Table 3. The IC50 Value of DPPH Scavenging- Activity

\begin{tabular}{|c|c|c|c|c|c|}
\hline \multicolumn{2}{|c|}{ Sample } & Equation & $\mathbf{R}_{\mathbf{2}}$ & $\begin{array}{c}\mathrm{C}_{50} \\
(\mu \mathrm{g} / \mathrm{ml})\end{array}$ & $\begin{array}{c}\text { Average IC } \mathrm{C}_{50} \\
(\mu \mathrm{g} / \mathrm{ml})\end{array}$ \\
\hline \multirow[t]{3}{*}{ Glycine max } & 1 & $Y=0.1735 x+30.066$ & 0.97 & 114.89 & \multirow{3}{*}{$116.52 \pm 2.50$} \\
\hline & $\begin{array}{l}2 \\
3\end{array}$ & $\begin{array}{l}Y=0.1766 x+28.914 \\
Y=0.2123 x+25.526\end{array}$ & $\begin{array}{l}0.97 \\
0.99\end{array}$ & $\begin{array}{l}119.40 \\
115.28\end{array}$ & \\
\hline & Mean & $Y=0.1875 x+28.168$ & 0.98 & 116.44 & \\
\hline \multirow[t]{4}{*}{ Daidzein } & 1 & $Y=0.2062 x+27.342$ & 0.99 & 109.88 & \multirow{4}{*}{$109.34 \pm 2.80$} \\
\hline & 2 & $Y=0.2190 x+26.718$ & 0.99 & 106.31 & \\
\hline & 3 & $Y=0.2112 x+26.380$ & 0.99 & 111.84 & \\
\hline & Mean & $Y=0.2121 x+26.813$ & 0.99 & 109.32 & \\
\hline \multirow[t]{4}{*}{ Glycine max } & 1 & $Y=0.1735 x+30.066$ & 0.97 & 114.89 & \multirow{4}{*}{$116.52 \pm 2.50$} \\
\hline & 2 & $Y=0.1766 x+28.914$ & 0.97 & 119.40 & \\
\hline & 3 & $Y=0.2123 x+25.526$ & 0.99 & 115.28 & \\
\hline & Mean & $Y=0.1875 x+28.168$ & 0.98 & 116.44 & \\
\hline \multirow{4}{*}{ Daidzein } & 1 & $Y=0.2062 x+27.342$ & 0.99 & 109.88 & \multirow{4}{*}{$109.34 \pm 2.80$} \\
\hline & 2 & $Y=0.2190 x+26.718$ & 0.99 & 106.31 & \\
\hline & 3 & $Y=0.2112 x+26.380$ & 0.99 & 111.84 & \\
\hline & Mean & $Y=0.2121 x+26.813$ & 0.99 & 109.32 & \\
\hline
\end{tabular}


Vol 5 No 1 February 2020

FARMATERA

E-ISSN: 2528-410X

Table 4. Tyrosinase Inhibition Assay

\begin{tabular}{lcc}
\hline $\begin{array}{c}\text { Concentration } \\
(\boldsymbol{\mu g} / \mathrm{ml})\end{array}$ & \multicolumn{2}{c}{ Tyrosinase Inhibition Activity (\%) } \\
\cline { 2 - 3 } & Glycine max (L.) Merr. & Daidzein \\
\hline 100 & $60.77 \pm 1.12^{\mathrm{d}}$ & $57.47 \pm 1.16^{\mathrm{e}}$ \\
50 & $42.66 \pm 0.66^{\mathrm{c}}$ & $44.36 \pm 0.97^{\mathrm{d}}$ \\
25 & $31.68 \pm 0.57^{\mathrm{b}}$ & $36.94 \pm 1.43^{\mathrm{c}}$ \\
12.5 & $30.57 \pm 0.80^{\mathrm{b}}$ & $32.02 \pm 0.72^{\mathrm{b}}$ \\
6.25 & $27.10 \pm 0.73^{\mathrm{a}}$ & $26.20 \pm 0.58^{\mathrm{a}}$ \\
3.13 & $27.48 \pm 0.72^{\mathrm{a}}$ & $24.73 \pm 0.42^{\mathrm{a}}$ \\
\hline Notes: & \\
Data were presented as mean \pm standard deviation. Different \\
small letters in the same column are significant at $P<.05$ \\
(Tukey HSD Post Hoc test).
\end{tabular}

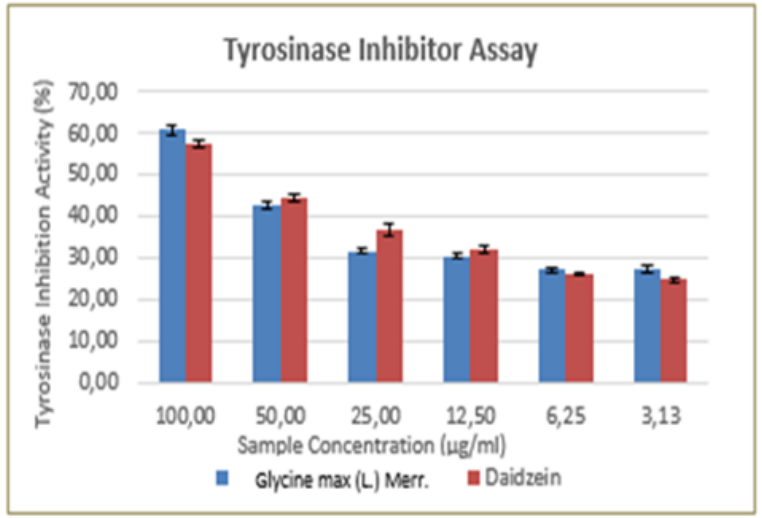

Figure 2. Various concentrations in tyrosinase inhibition activity

Table 5. The IC50 Value of Tyrosinase Inhibitor Activity

\begin{tabular}{cccccc}
\hline Sample & Equation & $\mathbf{R}_{\mathbf{2}}$ & $\begin{array}{c}\mathbf{I C}_{50} \\
(\boldsymbol{\mu} \mathbf{g} / \mathbf{m l})\end{array}$ & $\begin{array}{c}\text { Averange } \mathbf{I C}_{50} \\
(\boldsymbol{\mu} \mathbf{g} / \mathbf{m l})\end{array}$ \\
\hline Glycine max & 1 & $\mathrm{Y}=0.3676 \mathrm{x}+24.629$ & 0.99 & 69.02 & \\
& 2 & $\mathrm{Y}=0.3374 \mathrm{x}+25.489$ & 0.99 & 72.65 & $70.71 \pm 1.83$ \\
& 3 & $\mathrm{Y}=0.3483 \mathrm{x}+25.454$ & 0.99 & 70.47 & \\
\hline Daidzein & Mean & $\mathrm{Y}=0.3511 \mathrm{x}+25.191$ & 0.99 & 70.66 & \\
& 2 & $\mathrm{Y}=0.3385 \mathrm{x}+25.966$ & 0.97 & 71.00 & \\
& 2 & $\mathrm{Y}=0.3131 \mathrm{x}+26.236$ & 0.97 & 75.90 & $72.65 \pm 2.81$ \\
& 3 & $\mathrm{Y}=0.3327 \mathrm{x}+26.360$ & 0.97 & 71.06 & \\
\hline
\end{tabular}

Based on Tabel 4 and Figure 2, the tyrosinase inhibition activity of Glycine max (L.) Merr. was highest at a concentration of $100 \mu \mathrm{g} / \mathrm{ml}$ of $60.77 \pm 1.12 \%$ It was different at a concentration of $50 \mu \mathrm{g} / \mathrm{ml}, 25 \mu \mathrm{g} / \mathrm{ml}$, and $12.5 \mu \mathrm{g} / \mathrm{ml}$ where tyrosinase inhibition activity by Glycine $\max$ (L.) Merr). decreased with a percentage of $42.66 \pm 0.66$ $\%, 31.68 \pm 0.57 \%$, and $30.57 \pm 0.80 \%$. Daidzein compound inhibition activity was higher at the same concentration of $44.36 \pm 0.97 \%, \quad 36.94 \pm 1.43 \%$ and $32.02 \pm 0.72 \%$ and higher than the daidzein compound at the same concentration of $57.47 \pm 1.16 \%$.

Table 5 shows the Glycine max (L.) Merr). and daidzein compound showed that both could inhibit the tyrosinase enzyme with IC50 at $70.71 \pm 1.83 \mu \mathrm{g} / \mathrm{ml}$ and $72.65 \pm 2.81 \mu \mathrm{g} / \mathrm{ml}$.

\section{DISCUSSION}

The phytochemical screening is carried out as a preliminary stage which aims to determine the class of bioactive compounds in a plant studied. The selection of the solvent and extraction method is the most important factor in conducting a phytochemical screening assay. The phytochemical screening is done qualitatively using a color reagent and see the color changes that occur. Black soybean seeds (Glycine max (L.) Merr.) is known as 
E-ISSN: 2528-410X

nuts with nutritional value and is rich in protein. Not identified in our research, daidzein is one of the highest bioactive compounds in black soybean seeds and acts as an antioxidant (14) Therefore, daidzein was used as a comparison.

DPPH method is a simple method used to determine the antioxidant activity of plant material by capturing hydrogen atoms from the component of the extract of the plant. $\mathrm{DPPH}$ is sensitive to light, oxygen, and $\mathrm{pH}$. However, it is stable in a radical form so that it may be quite an accurate measurement of antioxidant activity. ${ }^{(15)}$

The lower the concentration shows the smaller the percentage of antioxidant activity of Glycine max (L.) Merr). and daidzein. Antioxidant activity with DPPH scavenging on daidzein compound was higher than Glycine $\max$ (L.) Merr). at concentration of $200 \mu \mathrm{g} / \mathrm{ml}, 100 \mu \mathrm{g} / \mathrm{ml}$, and $50 \mu \mathrm{g} / \mathrm{ml}$.

Glycine max (L.) Merr). and daidzein with DPPH scavenging activity obtained IC50 values averaging $116.52 \pm 2.50 \mu \mathrm{g} / \mathrm{ml}$ and $109.34 \pm 2.80 \mu \mathrm{g} / \mathrm{ml}$. The result was different from the previous study conducted by Fidrianny et al., the IC50 result by Glycine $\max (\mathrm{L}$.$) Merr. was 3.13 \mu \mathrm{g} / \mathrm{ml}$. (16) Kladna et al. reported the antioxidant test for several phytoestrogen compounds, one of which is daidzein, showed an IC50 result of $2.81 \pm 0.03 \mathrm{mM}$ through the DPPH scavenging method. (17) Both of these can be caused by different procedures in the extracted method, the solvent used and the different wavelengths in the DPPH method Tyrosinase or polyphenol oxidase is an oxidoreductase that participates in the biosynthesis of melanin, the main pigment found in hair, eyes, and skin. The tyrosinase enzyme reaction with the L-DOPA substrate produces an orange color. Inhibition activity of tyrosinase enzyme is characterized by a reduction in the orange color formed or the result of a clearer colored reaction. This also marks the presence of antioxidant activity in the reaction. ${ }^{(13)}$

Glycine $\max$ (L.) Merr). and daidzein compound showed that both could inhibit the tyrosinase enzyme with IC50 at $70.71 \pm 1.83 \mu \mathrm{g} / \mathrm{ml}$ and $72.65 \pm 2.81 \mu \mathrm{g} / \mathrm{ml}$. The tyrosinase enzyme inhibition study showed anti-tyrosinase activity produced by Glycine $\max$ (L.) Merr). and daidzein compound, according to Lai et.al (2012) using black soybean sprouts extract which has a strong activity of $98 \%$ in inhibiting the tyrosinase enzyme and can be used as a lightening agent in skin cosmetic product. (18) Another study by Sitanggang et al. also showed a positive correlation in inhibiting $>50 \%$ of the tyrosinase enzyme activity by yellow soybean. ${ }^{(19)}$

The effectiveness of a compound in biological or biochemical functions that can inhibit the oxidation process by $50 \%$ (IC50) is classified in several groups including $<50$ $\mu \mathrm{g} / \mathrm{ml}$ (very strong); $50-100 \mu \mathrm{g} / \mathrm{ml}$ (strong); $101-150 \mu \mathrm{g} / \mathrm{ml}$ (medium); $>150 \mu \mathrm{g} / \mathrm{ml}$ (weak).(20) In this study, the IC50 value in each test is grouped in Table 6 . 
Vol 5 No 1 February 2020

E-ISSN: 2528-410X

Table 6. The IC50 Value of Glycine $\max$ (L.) Merr.) and Daidzein

\begin{tabular}{lccc}
\hline \multicolumn{1}{c}{ Sample } & Assay & $\mathbf{I C}_{50}(\boldsymbol{\mu g} \mathbf{g} \mathbf{m l})$ & Activity \\
\hline Glycine max (L.) Merr. & \multirow{2}{*}{ DPPH assay } & $116.52 \pm 2.50$ & Medium \\
Daidzein & & $109.34 \pm 2.80$ & Medium \\
\hline Glycine max (L.) Merr. & \multirow{2}{*}{ Tyrosinase inhibition assay } & $70.71 \pm 1.83$ & Strong \\
Daidzein & & $72.65 \pm 2.81$ & Strong \\
\hline
\end{tabular}

\section{CONCLUSIONS}

Bioactive compounds that presence in black soybean (Glycine max (L.) Merr.) are saponin, tannin, triterpenoid, terpenoid, an alkaloid. Glycine $\max$ (L.) Merr.) and daidzein, both have antioxidant and tyrosinase inhibition activity as anti-aging. From the result, it shows that Glycine max (L.) Merr.) has tyrosinase inhibitor activity better than daidzein. Therefore Glycine max (L.) Merr.) can be developed into anti-aging ingredients in the product.

\section{ACKNOWLEDGEMENTS}

The author would like to thank DR. Ermi Girsang, SKM, M.Kes and dr. Ali Napiah Nasution, M.K.M as a mentor, DR. dr. I Nyoman Ehrich Lister, M.Kes., AIFM as head of the study program, dr. Linda Chiuman, M.K.M as dean, DR. Chrismis Nova linda Ginting, M.Kes as chancellor, and Aretha Medika Utama for supporting this research.

\section{REFERENCES}

1. Tobin DJ. Introduction to skin aging. Journal of tissue. 2016; 26(1):1-5.

2. Lai X, Wichers HJ, Soler-Lopez M, Dijkstra BW. Structure and Function of Human Tyrosinase and Tyrosinase-
Related Proteins. Chem. Eur. J. 2018; 24:50-53.

3. Siti ZR, Norkhadijah SIS, Praveena SM. Hazardous Ingredients in Cosmetics and Personal Care Products and Health Concern: A Review. Public Health Research. 2015; 5(1):1.

4. World Health Organization. Traditional Medicine Strategy. 2013.

5. Iris FFB \&Sissi WG. Herbal medicine :biomolecular and clinical aspects, 2nd Ed.New York: Taylor \& Francis Group, (Chapter 1). 2011.

6. Arifin AS. Kajian Morfologi Anatomi dan Agronomi antara Kedelai Sehat dengan Kedelai Terserang Cowpea Mild Mottle Virus serta Pemanfaatannya sebagai Bahan Ajar Sekolah Menengah Kejuruan. Jurnal Pendidikan Sains. 2013; 1(2):115.

7. Alghamdi et al. Comparative phytochemical profiling of different soybean (Glycine max (L.) Merr) genotypes using GC-MS. Saudi Journal of Biological Sciences. 2018; 25:15.

8. Sumardi et al. Potential of local black soybean as a source of the isoflavones daidzein and genistein. International Food Research Journal. 2017; 24(5):2140-2141.

9. Garg C. Khurana P, Garg M. Molecular Mechanisms of Skin Photoaging and 
E-ISSN: 2528-410X

Plant Inhibitors. International Journal of Green Pharmacy. 2017; 11(2):219-220.

10. Farnakope Herbal Indonesia. Jakarta: National Health Ministry; 2013.

11. Widowati et al. Antioxidant and Anti Aging Assays of Oryza Sativa Extracts, Vanillin and Coumaric Acid. Journal of Natural Remedies. 2016; 16(3):89-90.

12. Widowati et al. Antioxidant and Antiaging Activities of JasminumSambac Extract, and its Compounds. Journal of Reports in Pharmaceutical Sciences. 2018; 23(3):272-273.

13. Tu PTB, Tawata S. Anti-Oxidant, AntiAging, and Anti-Melanogenic Properties of the Essential Oils from Two Varieties of Alpiniazerumbet. Molecules. 2015; 20:16727-16728.

14. Altemimi A, Lakhssassi N, Baharlouei A, Watson DG, Lightfood DA. Phytochemicals: Extraction, Isolation, and Identification of Bioactive Compounds from Plant Extracts. Plants. 2017; 6:2-4.

15. Al-Kawaz HS, Al-Mashhady LAM. Evaluation of The Phytochemical Constituents and Oxidant-Amtioxidant Status for Actinidiadeliciosa Extracts.
International Journal of Pharmacy \& Therapeutics. 2016;7(1):35-36.

16. Fidrianny I, Elvianna D, Ruslan K. In Vitro Antioxidant Activities in Various Beans Extracts of Five Legumes from West of Java-Indonesia Using DPPH and ABTS Methods. International Journal of Pharmacognosy and Phytochemical Research. 2016; 8(3):471-474.

17. Kladna A. Berczynski P, Kruk I, Piechowska T, Aboul-Enein HY. Studies on the antioxidant properties of some phytoestrogens.Luminescence. 2016; 31(6).

18. Lai et al. Study of Active Ingredients in Black Soybean Sprouts and Their Safety in Cosmetic Use. Molecules. 2012; 17:11672.

19. Sitanggang SSDH, Yanti, Lay BW. Effect of Purified Protein Fractions from Soybean on Tyrosinase Inhibition. Sch. Acad. J. Biosci. 2017; 5(8):594.

20. Budaraga IK, Arnim, Marlinda Y, Bulanin U. Antioxidant Properties of Liquid Smoke Production Variation of Pyrolysis Temperature Raw and Different Concentration. International Journal of PharmTech Research. 2016; 9(6):370. 